\title{
41. Edebiyat halkalarının 5. sınıf öğrencilerinin okuma becerilerine etkisi ${ }^{1}$
}

\section{Halit KARATAY²}

\section{İlknur SOYSAL3}

\begin{abstract}
APA: Karatay, H.; Soysal, İ. (2021). Edebiyat halkalarının 5. sınıf öğrencilerinin okuma becerilerine etkisi. RumeliDE Dil ve Edebiyat Araştırmaları Dergisi, (22), 666-677. DOI: 10.29000/rumelide.897109.
\end{abstract}

\section{$\ddot{O} \mathbf{z}$}

$\mathrm{Bu}$ çalışmada edebiyat halkalarının 5. sınıf öğrencilerinin okuma becerileri üzerindeki etkisi incelenmiştir. Çalışma, sınıf içi eylem araştırması şeklinde tasarlanmıştır. Çalışma grubu 5. sınıfta okuyan 20 öğrenciden oluşmaktadır. Öğretmenin merkezde olduğu geleneksel okuma eğitimi etkinliklerinden farklı olarak Türkçe derslerindeki metinler 12 hafta boyunca edebiyat halkaları tekniği ile işlenmiştir. Öğrencilerin okuduğunu kavrama ve söz varlığı alanlarındaki gelişimi izlemek için OATı testi veri toplama aracı olarak kullanılmıştır. Ayrıca uygulama hakkında öğrencilerin görüşleri ve öğretmenin gözlemlerinden de yararlanılmıştır. Elde edilen veriler, edebiyat halkalarının öğrencilere özgüven kazandırdığını, yeni kelimeler öğrenmeye katkıda bulunduğunu, paragrafları kavramayı geliştirdiğini, eğlenceli bir yöntem olduğunu, metinleri derinlemesine incelemeye olanak tanıdığını ve sınıf içinde işbirliğini artırdığını göstermektedir. Öğrenciler ve öğretmene göre, okuma gruplarına üç öğrenciden fazla kişi katılmalıdır. Ayrıca öğrenciler çizim yapma konusunda zorlandıkları için çizer görevi yerine diğer görevleri tercih etmişlerdir.

Anahtar kelimeler: Edebiyat halkaları, okuduğunu anlama, okuma alışkanlığı, söz varlığı

\section{The effect of litterature circles on the reading reading skills of $5^{\text {th }}$ grade students}

\begin{abstract}
In order to help students deal with long and complex texts in their courses, they are taught text comprehension and analysis and In this study, the effect of literary circles on $5^{\text {th }}$ grade students' reading skills was examined. The study was designed as an in-class action research. The study group consists of $205^{\text {th }}$ grade students. Unlike the traditional reading education activities where the teacher is at the center, the texts in Turkish lessons were processed with the technique of literature circles for 12 weeks. The RCT1 test was used as a data collection tool to observe the development of students in reading comprehension and vocabulary. In addition, students' views and teachers' observations about the implementations were also used. The data obtained show that the literature circles give students self-confidence, contribute to learning new words, improve understanding the texts. Moreover, they are an entertaining method, allow for in-depth analysis of texts, and increase
\end{abstract}

Bu çalışma Soysal (2019)'ın "Edebiyat halkasının 5. sını öğrencilerinin okuma becerilerine etkisi” adlı yüksek lisans tezinden geliștirilmiştir.

2 Prof. Dr., Bolu Abant İzzet Baysal Üniversitesi, Eğitim Fakültesi, Türkçe ve Sosyal Bilimler Eğitimi Bölümü, Türkçe Eğitimi ABD (Bolu, Türkiye), halitkaratay@gmail.com, ORCID ID: 0ooo-0oo3-1820-0361 [Araştırma makalesi, Makale kaylt tarihi: 19.01.2021-kabul tarihi: 20.03.2021; DOI: 10.29000/rumelide.897109]

3 Türkçe Öğretmeni, Bolu TED Koleji (Bolu, Türkiye), nur_aykan_soysal@hotmail.com, ORCID ID: oooo-ooo2-83990200

RumeliDE Dil ve Edebiyat Araștırmaları Dergisi Osmanağa Mahallesi, Mürver Ciçeği Sokak, No:14/8 Kadıköy - İSTANBUL / TÜRKIYE 34714 e-posta: editor@rumelide.com tel: +90 $5057958124,+902167730616$
Address

RumeliDE Journal of Language and Literature Studies Osmană̆a Mahallesi, Mürver Çiçeği Sokak, No:14/8

Kadıköy - ISTANBUL / TURKEY 34714

e-mail: editor@rumelide.com,

phone: +90 505 7958124, +90 2167730616 
collaboration in the classroom. According to the students and the teacher, more than three students should join reading groups. In addition, students preferred other tasks to the task of drawing because they had difficulty in drawing.

Keywords: Literature circles, reading comprehension, reading habit, vocabulary

\section{Giriş}

Okullardaki bütün derslerdeki akademik başarıyı okuduğunu anlama etkilemektedir. Dolayısıyla okuduğunu anlama becerisi yetersiz olan öğrencilerin akademik başarılarının yüksek olması beklenemez. Öğrencilerin okuduğunu anlama becerilerini geliştirmenin öneminin farkında olan eğitimciler bu amaç için uzun yılardır pek çok strateji, yöntem ve teknik geliştirmiş ve uygulamışlardır (Akın ve Çeçen, 2014; Arı, 2014; Aydoğan ve Demirtaş, 2012; Doğan, 2006; Tercanlığlu ve Akarsu, 2012). Öğrencilerin okuduğunu anlayabilmeleri için okuma öncesi, okuma sırası ve sonrasında etkin olmaları, pek çok strateji ve tekniği kullanabilmelerine bağlıdır (Demirel ve Epçaçan, 2012, Karatay, 2018). Bu yöntemlerden birisi de edebiyat halkalarıdır. Edebiyat halkaları alanyazında farklı düzeyde ve amaçta pek çok çalışmaya konu olmuştur.

Edebiyat halkaları, kitap kulübü uygulamasının okul ortamına uyarlanması sonucu ortaya çıkmış bir yöntemdir. Yöntem ilk kez 1982 yılında Karen Smith tarafından uygulanmıştır. Edebiyat halkaları ismi ise ilk defa 1984 yılında Kathy Short ve Gloria Kaufman tarafından kullanılmıştır. Edebiyat halkaları, öğrencilerin kitap seçimleri doğrultusunda oluşturulan gruplarda, kitabın okudukları bölümlerini belirli aralıklarla tartıştıkları bir öğretim yöntemi olarak tanımlanmaktadır (Daniels, 2002). Edebiyat halkaları, bireysel okuma uygulaması ile işbirliği içinde çalışmanın birleştirilmiş hâlidir (Tracey ve Morrow, 2006).

Edebiyat halkaları farklı akademik başarı düzeyi ve okuma becerisine sahip olan öğrencilerin gönüllü olarak, öğretmenlerin ataması olmadan bir araya gelip kendi beğendikleri edebî bir metni kitap okumak ve daha sonra okuma deneyimlerini birbirleri ile paylaşmak için oluşturdukları 4-5 kişiden oluşan okuma gruplarıdır. Bu gruplara edebiyat halkaları denmesinin sebebi okuma gruplarında yer alan her bir öğrencinin metin ile ilgili edinmiş oldukları bilgi, deneyim ve izlenimleri birbirleriyle paylaşırken birbirlerinin yüzünü görmeyi sağlayan daire şeklinde oturmalarıdır (Karatay, 2015). Okuma sırasında öğrenciler okuma rollerini paylaşırlar, okuma görevleriyle ilgili notlar alırlar ve bu rollere göre metni tartışırlar. Edebiyat halkalarında düzenli olarak toplantılar yapılır ve oturumda tartışma rolleri değişebilir. Kitap veya ders kitabındaki okuma metni bittikten sonra grup üyeleri kendi okumalarını grup arkadaşlarıyla paylaşırlar. Sonrasında yeni bir metin veya kitap seçimi ile okuma ve tartışma döngüsü devam eder (Daniels, 2002; Karatay, 2015).

Edebiyat halkaları, öğretmenin sorular sorup öğrencilerin soruları yanıtlamasına dayalı geleneksel sınıf etkinliklerinden farklı olarak öğrenci-öğrenci, öğrenci-öğretmen iletişimine dayanır. Bu nedenle edebiyat halkalarında öğretmenlerin soru listeleri değil öğrencilerin anlayışları ve sorgulamaları tartışmayı yönlendirir (Brabham ve Villaume, 2000). Bu öğrenci merkezli tartışma ortamının oluşturulması öğrencilere verilecek olan görevler ile sağlanmaktadır. Edebiyat halkalarında yer alan görevler ile yöntemin uygulanışı kolaylaşmaktadır. Edebiyat halkalarında 4 zorunlu (ilişki kurucu, sorgulayıcı, bölüm-paragraf uzmanı, çizer), 4 seçmeli okuma görevi (özetleyici, araştırmacı, olay yeri açıklayıcısı, kelime dâhisi) vardır. Bunlar şu şekilde özetlenebilir:

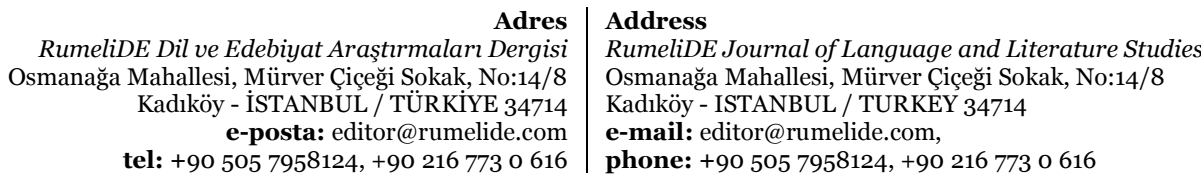


İlişki kurucu, okuma sırasında okuduğu hikâyelerdeki önemli bölümlerle kendi kişisel yaşamları, başkalarının yaşamları veya diğer hikâyelerle çeşitli bağlantılar kurar (Daniels, 2002; Marchiando, 2013). Sorgulayıcı, bilgi düzeyinden analiz düzeyine kadar farklı düzeylerde sorular hazırlar. Grup üyelerinin davranışlarından ve tartışmaları dinleyerek tartışmalara katılmalarından sorumlu olan kişidir (Barone ve Barone, 2016; Karatay, 2015). Bölüm-paragraf uzmanı, okuduğu kısımlarla ilgili bölümler seçerek grup içinde arkadaşlarıyla paylaşır. Bu bölümleri neden seçtiğini açılar. (Daniels, 2002). Çizer, okuduğu bölümün kendisinde uyandırdı̆̆ı duygu ile ilgili bir ürün ortaya koyar. Bu ürünün daha çok bir resim olması istenir. Resim dışında, karikatür, kavram haritası, akış şeması, kolaj vb. ürünler de olabilir (Daniels, 2002; Tracey ve Morrow, 2006; Karatay, 2015).

Özetleyici, okunan bölümle ilgili kısa bir özet sunar. Yalnızca okunanlardaki ana olaylarla ilgili önemli durumları anlatır (Daniels, 2002). Araştırmacı, kitapta anlatılan yerle ilgili iklim, kültür ve coğrafyaya yönelik bilgiler ile tarihî bilgiler; yazarın yaşamıyla ve diğer kitaplarıyla ilgili bilgiler; kitapta anlatılan zaman dilimi/dönemle ilgili özel bilgi; kitapta kullanılan resimler, nesneler, şekiller veya materyallerle ilgili bilgiler, kitapta kullanılan isimler ve sözcüklerin kökeni ve tarihi hakkında bilgi toplar ve grup üyeleriyle paylaşır (Daniels, 2002). Kelime dâhisi, okunan bölümde anlamı bilinmeyen, farklı anlamlarda kullanılan veya özel anlamlar içeren sözcükleri tespit eder. Seçilen sözcükler çok kez tekrar edilmiş, farklı bir biçimde kullanılmış ve metnin/kitabın anlamı için anahtar sözcükler olabilir. (Daniels, 2002). Olay yeri açılayıcısı, karakterlerin hareket ettiği ve olayların geçtiği yerleri ayrıntılı biçimde anlatır (Daniels, 2002).

Okuma modeli olarak farklı öğretim düzeylerinde uygulanabilen edebiyat halkaları öğrencilerin sadece okuduğunu anlama becerilerini geliştirmekle kalmamakta aynı zamanda konuşma ve yazma becerilerini; birbirleri ile iletişim kurma, işbirlikli öğrenme gibi sosyal becerilerini de geliştirdiği bilinmektedir.

\section{Araştırmanın amacı}

Alanyazında bu konu ile ilgili yapılan çalışmalar, öğrencilerin gönüllü olarak seçip okudukları kitaplar üzerinden yapılmıştır. Türkçe ders kitaplarındaki okuma metinlerini bu yönteme göre derslerde işleyip sonuçları değerlendirilmemiştir. Okullarda Türkçe derslerinde öğrencilerin okuduğunu anlama ve söz dağarcığını geliştirmek amacıyla okunan metinler, geleneksel okuma etkinlikleri ile işlenmektedir. Geleneksel okuma çalışmalarında sınıfta öğretmenler etkin, öğrenciler ise edilgindir. Okuma çalışmalarında metin önce öğretmen ve/veya okuma becerisi iyi olan bir öğrenci tarafından sesli okunur. Diğer öğrenciler de metni bir iki kez sesli veya sessiz okurlar. Bu okuma çalışmalarında öğrencilerin akıcı okumaları için takıldıkları sözcükleri doğru telaffuz etmelerine yardımcı olunur; bürünsel okuma becerilerini geliştirmek için de noktalama işaretlerine uygun durak, vurgu ve tonlama yapmaları sağlanır. Okuma çalışması bittikten sonra, metinde geçen anlamı bilinmeyen kelimeler üzerine etkinlikler ve metni anlama-çözümleme $(5 \mathrm{~N} 1 \mathrm{~K})$ çalışmaları yapılır. Okuma eğitimi çalışmalarına katılma öğrencilerin isteği, özgüveni ve öğretmenin teşvik etmesine bağlıdır. Bu okuma eğitimi anlayışında öğrenciler, birbiri ile değil, sürekli öğretmen ile etkileşim hâlindedirler. Dolayısı ile öğrenciler arasında sınıf içi iletişim çok yönlü değildir ve sürekli aynı öğrenciler derse katılabilmektedir. Edebiyat halkalarında ise gruptaki her öğrencinin okunan metin ile ilgili yapacağı bir görevi vardır. Öğrenciler, okuma görevleri doğrultusunda metni bağımsız okur ve bununla ilgili geliştirdikleri ürünü arkadaşları ile paylaşırlar. Böylelikle hem bireysel, bağımsız olarak okuma eylemine etkin katılır hem de arkadaşları ile bunları paylaşarak onlarla etkileşimde bulunurlar.

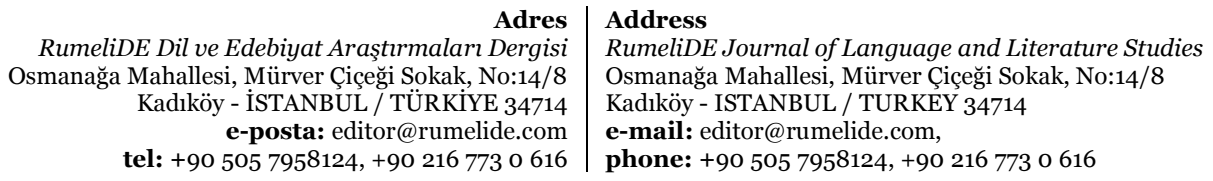


$\mathrm{Bu}$ araştırmada Türkçe derslerindeki geleneksel okuma etkinlikleri yerine edebiyat halkaları yöntemi kullanılarak okuma metinleri işlenmiş, edebiyat halkalarının 5. sınıf öğrencilerinin okuma becerileri üzerine etkisi çeşitli değişkenler açısından incelenmiştir. Araştırmada şu sorulara cevap aranmıştır:

1. Edebiyat halkaları, öğrencilerin söz varlığı, metni anlama ve çözümleme, konu ve ana düşünce bulma becerileri üzerinde etkili midir?

2. Edebiyat halkaları, öğrencilerin cinsiyetine göre okuduğunu anlama düzeyleri üzerinde etkili midir?

3. Edebiyat halkaları okuma etkinlikleri ile ilgili öğrencilerin görüşleri nelerdir?

4. Edebiyat halkaları okuma etkinlikleri ile ilgili öğretmen gözlemleri nelerdir?

\section{Araştırmanın yöntemi ve tasarımı}

Araştırma sınıf içi eylem araştırması olarak tasarlanmıştır. Eylem araştırmaları uzman araştırmacı yürütücülüğ̈̈nde, uygulayıcıların ve probleme taraf olanların katılımıyla, mevcut uygulamanın eleştirel değerlendirmesinin yapılarak durumun iyileştirilmesine yönelik alınması gereken önlemlerin belirlenmesini amaçlar (Karasar, 2016). Araştırma şu aşamalara göre tasarlanmıştır:

1. Geleneksel uygulamaların değerlendirilmesi: 2018-2019 eğitim-öğretim yllında öğrencilerin Türkçe ders kitaplarında yer alan okuma etkinlikleri incelenmiştir. Mevcut okuma etkinlikleri içerisinde edebiyat halkaları uygulaması olmadığı görülmüştür.

2. Eylem araştırması sürecinde hedeflerin belirlenmesi: Edebiyat halkaları yöntemi aracılığıyla okuma ve okuduğunu anlama becerilerinin geliştirilmesinde kullanılacak etkinliklerin tespit edilmesine çalışılmıştır.

3. Uygulama etkinliklerinin geliştirilmesi için yöntemlerin betimlenmesi: Öğrencilerin edebiyat halkaları etkinliklerinde kullanılabilecekleri okuma metinlerine karar verilmiştir. Metinlerin belirlenmesinin ardından yöntem hakkında sınıf bilgilendirilmiştir. $\mathrm{Bu}$ bilgilendirmede sorgulayıcı, paragraf uzmanı, ilişki kurucu ve çizer görevlerinin yer alması zorunlu olduğundan grupların dört kişiden oluşacağı söylenmiştir.

4. Ön uygulama ve planın iyileştirilmesi: Ön uygulama çalışmaları yapılıp planın uygulanabilir olup olmadığı, eksik olan taraflarının iyileştirilmesi için yapılacak olan çalışmalar kararlaştırılmıştır.

5. Yenilenmiş planın uygulanması: Sınıf mevcudu 20 kişi olduğundan her uygulama için dört kişiden oluşan beş okuma grubu oluşturulmuştur.

6. Eylem planının uygulanmasından elde edilen verilerin çözümlenmesi, raporlaştırılması ve paylaşılması: Okuma etkinliklerinin uygulanmasından sonra öğrencilerin okuma becerilerindeki değişim değerlendirilmiştir. Öğrencilere uygulama öncesi ve sonrasında okuduğunu anlama başarı testi uygulanmıştır. Her iki testten elde edilen ortalama puanlar karşlaş̧ırılarak kullanılan okuma yönteminin etkisi değerlendirilmiştir.

\footnotetext{
Adres $\mid$ Address

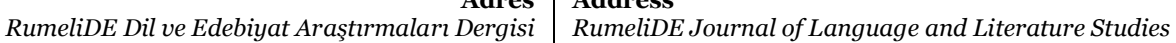
Osmanağa Mahallesi, Mürver Çiçeği Sokak, No:14/8 Osmanağa Mahallesi, Mürver Çiçeği Sokak, No:14/8 Kadıköy - ISTANBUL / TÜRKIYE 34714 Kadıköy - ISTANBUL / TURKEY 34714 e-posta: editor@rumelide.com e-mail: editor@rumelide.com, tel: +90 505 7958124, +90 2167730616 phone: +90 505 7958124, +90 2167730616
} 


\section{Veri toplama araçları ve süreci}

Edebiyat halkaları yönteminin öğrencilerin okuma becerileri üzerindeki etkisini belirlemek amacıyla 20 sorudan oluşan "Okuduğunu Anlama Testi 1 (OAT1)" kullanılmıştır (Karatay, 2018). OAT1'de iki farklı metin ve bu metinlere bağlı 20 adet çoktan seçmeli soru vardır. Bu test uygulama öncesi (ön test) ve sonrası (son test) olmak üzere iki kez uygulanmıştır. Çalışmada kullanılan OATı'de yer alan maddeler söz varlığı, okuduğunu anlama ve çözümleme, konu ve ana düşünceyi bulmaya yöneliktir. $\mathrm{Bu}$ testte, söz varlığı ile ilgili 12 tane madde vardır (bk. S1,2,3,4,10,11,12,13,14,15,16,17). Metni anlama ve çözümleme ile ilgili 4 tane soru vardır (bk. S5,7,19,20) Konu ve ana düşünce ile ilgili de 4 tane soru vardır $(\mathrm{S} 6,8,9,18)$. OAT1'deki 20 maddenin güçlük indeksinin 0,36 ile 0,89 arasında değişiklik gösterdiği görülmektedir. Maddelerin ayırt edicilik indeksleri de 0,25 ile 0,54 arasında değişmektedir. Maddelerin bilen öğrenci ile bilmeyen öğrenciyi birbirinden orta ya da yüksek düzeyde ayırt edebildikleri belirlenmiştir (Karatay, 2016).

Öğrencilerin edebiyat halkaları yöntemine ilişkin görüşlerini almak için 3 soruluk bir "Mülakat Formu” hazırlanmıştır. Bu çalışma kapsamında hazırlanan sorularda, öğrenci düzeyi dikkate alınmıştır. Uygulanan yöntem ile ilgili duygu ve düşünceleri ortaya çlkarabilmek amacıyla üç soruya yer verilmiştir. Sorular hazırlanırken uzman görüşü alınmıştır. Sorular: "Edebiyat halkalarının beğendiğiniz yönleri nelerdir?”, "Diğer metin okuma etkinliklerine göre edebiyat halkalarını nasıl buldunuz?", "Edebiyat halkaları okuma etkinliklerinde beğenmediğiniz yönler nelerdir? Bu uygulamaların daha iyi olması için neler önerirsiniz?” şeklindedir. Uygulama etkinlikleri tamamlandığında uygulamalar hakkında öğrenci görüşleri alınmıştır. Ayrıca, uygulama süresince öğretmenin tuttuğu günlüklerden yararlanılmıştır.

\section{Çalışma grubu}

Araştırmanın çalışma grubunu Bolu'da özel bir ortaokulda öğrenim gören 5. sinıf öğrencileri oluşturmaktadır. Bu öğrencilerin 11’i (\%55) kız, 9’u (\%45) erkektir.

\section{Okuma metinleri}

Araştırmada kullanılmak üzere 2017-2018 eğitim-öğretim yılı MEB 5. sınıf Türkçe ders kitabından araştırmacı tarafından uzman ve öğrenci görüşleri de alınarak on metin seçilmiştir. Metinlerin bu kitaptan seçilmesinin amacı MEB’in bu sınıf düzeyi için onayladığı kitaplardan olmasıdır. Seçilen metinler: "Oyuncak (Erdoğan Tokmakçığlu), Alis Harikalar Diyarında-Tavşanın Peşinden (Lewis Carroll), Güneşin Uyuduğu Yer (Mevlâna İdris Zengin), Küçük Ağa (Tarık Buğra), Güvercin (Beydeba), Forsa (Ömer Seyfetin), Çocuk Doğru Söyledi (Başak Çocuk Dergisi), Hasta (Memduh Şevket Esendal), Kar Tanesinin Serüveni (Samed Behrengi), Ben Bir Çınar Ağacıydım (Şevket Yücel).

\section{Uygulama süreci}

Uygulamalar, 2017-2018 eğitim-öğretim yllının 2. döneminde Türkçe derslerinde toplamda 12 hafta yapılmıştır. Bu çalışmalar, ilk iki hafta edebiyat halkalarına öğrencileri hazırlama ve okuduğunu anlama becerilerinin belirlenmesi-ön test (OAT1), on hafta edebiyat halkaları okuma etkinlikleri şeklindedir. Uygulamaların son haftasında tekrar bir ders saatinde son test (OAT1) uygulanmıştır.

Uygulamanın ilk haftası, öğrenciler okuma gruplarını oluşturmuş, okuyacakları metni ve okuma görevlerini gönüllüce seçmişlerdir. Uygulamalar her hafta farklı metinlerle devam etmiştir. Her

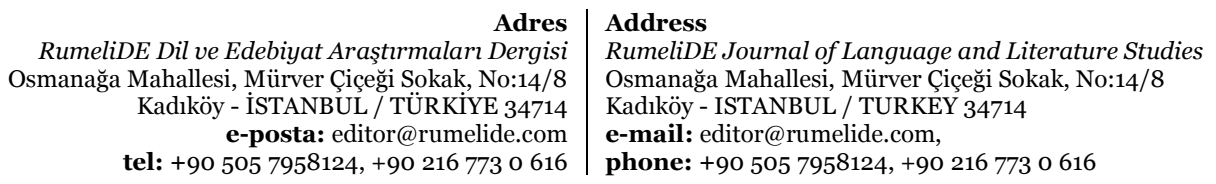


uygulamadan önce öğrenciler haftanın bir günü bir ders saati edebiyat halkalarında okuyacakları metni ve alacakları görevleri belirlemek için toplanmışlardır. Okuma işini evde yapan öğrenciler bu toplantılarda kendi görevleri ile ilgili grup içinde paylaşımlarda bulunmuştur.

\section{Verilerin analizi}

Çalışmada okuduğunu anlama ile ilgili veriler SPSS 21.0 paket programı ile analiz edilmiştir. Tanımlayıcı istatistikler olarak ortalama, standart sapma ve yüzdeler verilmiştir. Öğrencilerin cinsiyetine göre ön-son test başarı puanlarının karşılaştıılmasında Mann Whitney U testi, cinsiyetten bağımsız olarak ön-son test başarı puanları arasında farklılık olup olmadığının belirlenmesinde tekrarlı ölçümler $\mathrm{t}$ testi kullanılmıştır. Elde edilen sonuçlar \% 95 anlamlılık düzeyinde değerlendirilmiştir. Öğrencilerin edebiyat halkaları yöntemiyle ilgili görüşlerini tespit etmek için sorulan sorulara verilen yanıtların içerik analizi yapılmıştır. Öğrencilerden alınan görüşler ana ve alt temalar altında, her bir öğrencinin görüşü ‘K1, K2...’ şeklinde kodlanarak sunulmuştur.

\section{Bulgular}

Bu bölümde, araştırmanın nicel ve nitel verilerine yer verilmiştir.

Birinci soru: $\mathrm{Bu}$ sorunun çözümlenmesinde öğrencilerin OAT1 ön-son test puanlarının karşılaştırılmasından elde edilen verilerden yararlanılmıştır. Bununla ilgili bulgular Tablo 1'de verilmiştir.

\begin{tabular}{|c|c|c|c|c|c|c|}
\hline Grup & Okuduğunu anlama düzeyi & $\mathbf{x}$ & $\mathbf{N}$ & $\mathbf{S}$ & $\mathbf{t}$ & $\mathbf{p}$ \\
\hline \multirow{2}{*}{ 1. Boyut } & Söz varlığı (ön test) & 41,50 & 20 & 7,27 & \multirow{2}{*}{-.353} & \multirow{2}{*}{.728} \\
\hline & Söz varlığı (son test) & 40,75 & 20 & 9,49 & & \\
\hline \multirow{2}{*}{ 2.Boyut } & Metni anlama ve çözümleme (ön test) & 9,75 & 20 & 4,12 & \multirow{2}{*}{-3.115} & \multirow{2}{*}{.006} \\
\hline & Metni anlama ve çözümleme (son test) & 13,00 & 20 & 4,97 & & \\
\hline \multirow{2}{*}{ 3. Boyut } & Konu ve ana düşünce (ön test) & 11,25 & 20 & 3,35 & \multirow{2}{*}{-3.269} & \multirow{2}{*}{.004} \\
\hline & Konu ve ana düşünce (son test) & 14,25 & 20 & 4,25 & & \\
\hline
\end{tabular}

Tablo 1. Okuduğunu anlama ile ilgili ön-son test puanları

Öğrencilere uygulanan OATı'deki soru gruplarına göre ön-son test puanları arasında anlamlı fark olup olmadığı yapılan tekrarlı ölçümler $\mathrm{t}$ testi ile sınanmıştır. Buna göre, edebiyat halkalarını uygulama etkinlikleri öğrencilerin okudukları metni anlama ve çözümleme [t(19) = -3.115, p = 0.006] ile konu ve ana düşünceyi doğru bulma [t(19) $=-3.269, \mathrm{p}=0.004]$ becerilerini anlamlı düzeyde geliştirmiştir. Ayrıca öğrencilerin söz varlığında anlamlı bir değişme olmadığı [t(19) $=.353, \mathrm{p}=0.728]$ belirlenmiştir.

İkinci soru: $\mathrm{Bu}$ sorunun çözümlenmesinde cinsiyete göre OAT1 ön-son test puanlarının karşlaştırılmasından elde edilen verilerden yararlanılmıştır. Bununla ilgili bulgular Tablo 2'de verilmiştir. 


\begin{tabular}{lllllll}
\hline & Cinsiyet & $\mathbf{N}$ & $\mathbf{X}$ & Sd ( \pm ) & U & p \\
\hline \multirow{2}{*}{ Ön test } & Erkek & 9 & 50.22 & 8.51 & \\
\cline { 2 - 6 } & $\mathbf{K 1 z}$ & 11 & 49.81 & 8.26 & 908 \\
\hline \multirow{2}{*}{ Son test } & Erkek & 9 & 54.66 & 6.92 & \\
\cline { 2 - 6 } & $\mathbf{K 1 z}$ & 11 & 54.18 & 10.48 & 1.000 \\
\hline
\end{tabular}

Tablo 2. Öğrencilerin cinsiyete göre ön-son test başarı puanları

Öğrencilerin cinsiyetine göre ön-son test başarı puanları arasında anlamlı farklılık olup olmadığı Mann Whitney U testi ile incelenmiştir. Buna göre, hem ön hem de son uygulamada öğrencilerin cinsiyetine göre okuduğunu anlamanın farklılaşmadığı belirlenmiştir.

Üçüncü soru: Bu sorunun çözümlenmesinde uygulama hakkında öğrencilerden alınan görüşlerden yararlanılmıştır. Öğrencilerin bu okuma yöntemi ile ilgili görüşleri olumlu ve olumsuz görüssler olmak üzere iki ana başlıkta toplanmıştır. Bununla ilgili bulgular Tablo 3 ve 4 ’te verilmiştir.

\begin{tabular}{lll}
\hline Edebiyat halkalarının olumlu yönleri & Katılımcılar & $\mathbf{n}$ \\
\hline 1. Metni çözümlemeyi öğretmesi & $\mathrm{K}_{2,3,5,6,8,11,12,13,16,17,18,19,20}$ & 13 \\
\hline 2. Dersin eğlenceli olması & $\mathrm{K}_{1,3,4,7,10,14,15,18,19}$ & 9 \\
\hline 3. Öğrencinin etkin katılması & $\mathrm{K}_{5,7,8,9,10,11,12}$ & 7 \\
\hline 4. Özgüveni geliştirmesi & $\mathrm{K}_{13,15}$ & 2 \\
\hline
\end{tabular}

Tablo 3. Edebiyat halkalarının olumlu yönleri

Uygulamaya katılan öğrencilerin 13’ü edebiyat halkalarının metni çözümlemeyi öğrettiğini belirtmiştir. Dokuz öğrenci de bu tür okuma etkinliklerinin dersi daha eğlenceli yaptığını; yedi öğrenci ise kendilerinin derse daha etkin katıldığını belirtmiştir. İki öğrenci de bu uygulamalar sayesinde okuma çalışmalarında sorumluluk alma konusunda özgüven kazandığını belirtmiştir.

\begin{tabular}{lll}
\hline Edebiyat halkalarının olumsuz yönleri & Katılımcılar & $\mathbf{n}$ \\
\hline Çizim yapmak zor & $\ddot{O}_{1,4,10}$ & 3 \\
\hline Görev dağılımı & Ö6 & 1 \\
\hline Gerçek hayatla ilişkilendirme güçlüğü & $\ddot{O}_{15}$ & 1 \\
\hline Grubu oluşturan kişi sayısının az olması & $\ddot{O ̈} 16$ & 1 \\
\hline Soruların sadece bir kişiye sorulması & $\ddot{O}_{17}$ & 1 \\
\hline
\end{tabular}

Tablo 4. Edebiyat halkalarının olumsuz yönleri

Öğrencilerin 7'si edebiyat halkalarında zorlandıklarını belirtmiştir. Öğrencilerin 3’ü çizer rolündeki kişinin çizim yapmasının zor olduğunu; 1 kişi gruptaki görevlerinin sabit kalmasını, başka görev almamayı beğenmediğini; 1 kişi ilişki kurucu görevindeki öğrencilerin okunanları günlük hayatla ilişkilendirmede zorlandığını; 1 kişi okuma halkalarındaki sayının az olduğunu ve 1 kişi de soruların sürekli 1 kişi tarafından cevaplanmasını beğenmediğini belirtmiştir.

Dördüncü soru: Bu sorunun çözümlenmesinde uygulama süreci ile ilgili öğretmenin tuttuğu günlüklerden yararlanılmıştır. Uygulama öğretmeninin edebiyat halkaları ve uygulama süreci hakkındaki görüşleri şöyledir:

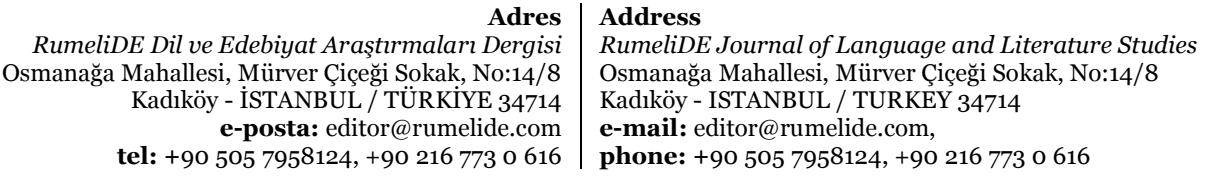


İş birliği: Öğrencilerin çalışma süresince birbirleri ile anlaşabilmelerini sağlamak için gruplar oluşturulurken istekleri ön planda tutuldu. Öğrenciler hangi metni incelemek istiyorsa o metni inceleyen gruba katıldı. Öğrenciler edebiyat halkalarında istedikleri görevleri aldılar. Öğrenciler, metinleri incelerken görev değişikliğine gitmek istemediler. Bazı gruplarda buna itiraz eden öğrenciler olsa bile sınıfın ortak kararından dolayı herkes aynı görevleri üstlendi. Metin incelemelerinde de birbirlerine danışarak görevlerini yerine getirdiler. Sınıf içinde öğrencilerle verilen kararlar onları çok mutlu etti. Bu yüzden hem gruplar oluşturulurken hem de metinler seçilirken herhangi bir sorun yaşanmadı ve sadece öğrencilere rehberlik edildi. Bu uygulamalar boyunca öğrenciler birbiri ile iş birliği içerisinde çalıştılar.

Etkin katılım: Her öğrencinin kendini bir gruba ait hissetmesi onların etkinliklerde etkin olarak rol almasını sağladı. Normalde sınıf içinde varlığını çok gösteremeyen öğrencilerin bile grup içinde aldıkları rolleri yerine getirirken söz sahibi olmaları onlarda güven duygusu oluşturdu. Tek başınayken sessiz olan öğrencilerin grup içinde arkadaşlarının desteğiyle de söz almaları kolaylaştı. Uygulamanın en güzel yanı da tartışmaya katılmayan hiçbir öğrencinin kalmamış olmasıydı.

Okuma becerisini geliştirme: Geleneksel okuma etkinliklerinin aksine metni, bir görevi yerine getirmek için okuyup grup içinde tartışmak okuduğunu anlamada kolaylık sağlamıştır. Sadece tartışma grubu içinde olamayıp dinleyici grubunda bile olmak, metnin anlaşılmasını kolaylaştırdığı gibi akılda kalmasını da sağlamıştır.

Okuma etkinliklerine katılma isteğini artırma: Türkçe derslerinde geleneksel yöntemle işlenen metinler dersi sıkıcı hâle getirmekteydi. Geleneksel okuma etkinliklerinde bazı öğrencilerin metni anlamadığı da gözlemlenmiştir. Bu yüzden edebiyat halkaları yöntemi okuma etkinliklerini sıkıcılıktan kurtararak okuduğunu anlamayı kolaylaştırmış, dersi daha eğlenceli hâle getirmiştir. Bu da Türkçe dersine olan öğrenci tutumlarını olumlu yönde etkilemiştir. Farklı bir etkinlikle bir metni okumak öğrencilerde okuma isteğini de artırmıştır.

Uygulamada dikkat edilmesi gerekenler: Çizer rolünü üstlenen öğrencilerden bazıları çizim becerileri iyi olmadığı için zorlanmışlardır. Çizim becerisi iyi olmayan öğrencilerin bu rolü almaması gerekmektedir. Dinleyici grubunda bazı öğrencilerin kendi aralarında konuşmaları grup üyelerinin dikkatini olumsuz etkilemiştir. $\mathrm{Bu}$ nedenle uygulamanın aksamaması için ara ara öğrenciler uyarılmıştır.

\section{Tartışma ve sonuç}

Okuduğunu anlama, metni sadece yüzeysel anlamayı değil aynı zamanda metni çözümleme, yorumlama ve değerlendirmeyi de içerir. Okuduğunu anlama düzeyi bireyin gelişim düzeyine göre değişir. Ayrıca kişinin okuduğunu anlama becerisi, hafızayı kullanma, dikkat, mantıksal çıarımda bulunabilme kabiliyetleri, kitap okuma nedeni, öz yeterlik algısı, dilbilgisine hâkimiyet gibi pek çok değişkenden de etkilenir. Temel okuryazarlıktan itibaren bu becerilerin büyük bölümü kademeli olarak gelişir. Zamanla öğrencinin söz varlığı, okuma akıcılığı, ilgisi ve alışkanlığı, alan bilgisi, okuma hızı artar (Snow, 2002); kitabın özelliğine bağlı olarak konuya karşı ilgi ve kendilik algısı gelişir.

Edebiyat halkalarını temel eğitimin birinci kademesinden başlayıp ortaöğretime kadar uygulayan öğretmenler bu yöntemin öğrencilerin yalnızca okuma ve anlama becerilerini değil, özellikle okumaya karşı isteksiz olan çocukların okuma isteği ve alışkanlıklarını, yazma ve konuşma becerilerini, aynı

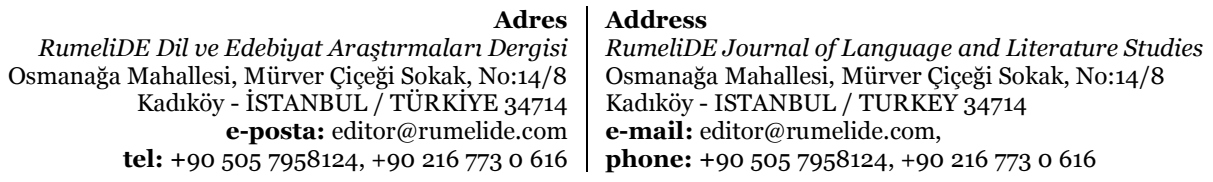


zamanda öğrencilerin özgüvenlerini geliştirdiğini ifade etmişlerdir (Karatay, 2017). Edebiyat halkaları ayrıntılı okuma yapılması ile okuduğunu anlamayı; farklı görevlerin grup içerisinde yerine getirilmesi ile iş birlikli öğrenmeyi; bölüm tartışmalarıyla öğrencinin konu üzerinde düşünüp değerlendirmede bulunarak eleştirel düşünmeyi sağlar.

Çalışmaya dâhil edilen öğrencilerin ön test başarı puan ortalamaları dikkate alındığında edebiyat halkaları yönteminin okuduğunu anlama becerilerinin geliştirilmesinde etkili bir yöntem olduğu söylenebilir. Avcı vd., (2013) tarafından edebiyat halkalarının ilköğretim beşinci sınıf öğrencilerinin okuduğunu anlama becerileri üzerindeki etkisinin belirlenmesi amaciyla 67 öğrenci üzerinde gerçekleştirilen çalışmada edebiyat halkaları yöntemi ile ders işlenen deney grubunda yer alan öğrencilerin son test başarı puanlarının ön test puanlarından anlamlı şekilde yüksek olduğu bildirilmiştir.

Bu çalışmaya dâhil edilen öğrencilerin cinsiyetine göre ön test ve son test başarı puanları arasında farklılık olup olmadığını tespit etmek için yapılan Mann Whitney U testi sonucunda erkek öğrencilerin ön-son test başarı puanı ortalamalarının kızlardan az da olsa yüksek olduğu, gruplar arasındaki farkın anlamlı olmadığı görülmüsstür. Öğrencilerin okuduğunu anlama testindeki soru gruplarından uygulama öncesi (ön test) ve uygulama sonrası (son test) puanlarının cinsiyetlerine göre farklılık arz edip etmediğini belirlemek için yapılan Mann Whitney $U$ testi neticesinde anlaml farklılık saptanmamıştır. Cinsiyetin dil gelişimindeki rolüyle ilgili iki farklı düşünce bulunmaktadır. Bunlardan ilki cinsiyetin dil gelişiminde belirleyici bir faktör olmadığı, diğeri de kadınların dil ve kavram gelişiminin erkeklere göre daha başarılı olduğudur (Keklik, 2009). Yapılan çalışmaların genellikle ikinci görüşü desteklediği görülmektedir. Zira uluslararası eğitimde verimlilik araştırmalarında kadınların bilhassa okuma ve metinleri anlama noktasında erkeklerden önde olduğu bildirilmiştir (Kavaklı, 2012). Arslan, Orhan ve Akçay (2011) tarafından 2006-2010 arası dönemindeki 47 yüksek lisans ve doktora tezinin incelendiği çalışmada kadınların dil becerilerinin erkeklerden daha iyi düzeyde olduğu bildirilmiştir. Sallabaş (2008) tarafından ilköğretim sekizinci sınıf öğrencileri üzerinde gerçekleştirilen çalışmada kı öğrencilerin okuduğunu anlama becerilerinin erkek öğrencilerden anlamlı şekilde yüksek olduğu bildirilmiştir. Bu çalışmada ise erkek öğrencilerin kız öğrencilere göre okuduğunu anlama becerisinin az da olsa daha iyi olduğunu göstermektedir.

Çalışmada uygulanan OAT1 "söz varlığı soruları", "metni anlama ve çözümleme soruları" ve "konu ve ana düşünce soruları" olmak üzere üç boyuttan oluşmaktadır. Edebiyat halkaları etkinlikleri öğrencilerin metni anlama ve çözümleme ile konu ve ana düşünceyi bulma becerilerini olumlu yönde geliştirmiştir. Öğrenciler, bu uygulamalar sayesinde metni daha iyi çözümlemeyi öğrendiklerini belirtmişlerdir. Bu çalışmadan önce edebiyat halkalarının Mizerka (1999) beşinci sınıf öğrencilerinin; Olsen (2007) dokuzuncu sinıf öğrencilerinin; Camp (2006) on birinci sinıf öğrencilerinin; Briggs (2010) üçüncü sınıf öğrencilerinin; McElvain (2010) 4-6. sınıf öğrencilerinin; Avcı ve Yüksel (2011) dördüncü sınıf öğrencilerinin; Avcı vd., (2013) beşinci sınıf öğrencilerinin; Purifico (2015) üçüncü sinıf öğrencilerinin; Meredith (2015) ikinci sınıf öğrencilerinin; Balantekin ve Pilav (2017) 7. sinıf öğrencilerinin; Karatay (2017) Türkçe öğretmenliği adaylarının okuduğunu anlama becerileri üzerinde etkili olduğunu belirlemişlerdir. Edebiyat halkalarının, okuduğunu anlama becerileri üzerindeki etkisine rağmen bu çalışmada öğrencilerin söz varlığında istenilen düzeyde gelişim olmamıştır. Öğrencilerin genel olarak metinde geçen sözcük ve sözcük gruplarının anlamlarını tahmin etmede zorlandıkları gözlemlenmiştir. Bu nedenle okuduğunu anlamanın önemli bir bileşeni olan söz varlığını geliştirmek için bu tür okuma etkinliklerinde söz varlığı çalışmalarına ağırlık verilmesi gerektiği söylenebilir.

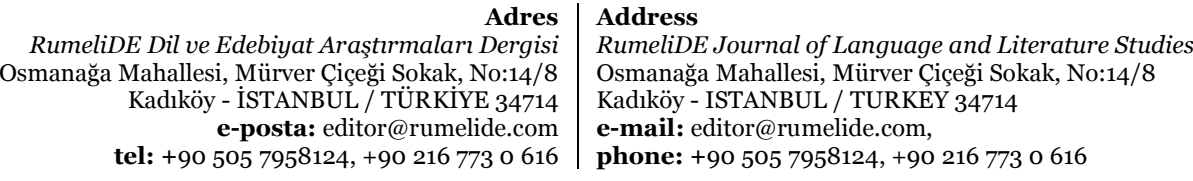


Öğrenciler edebiyat halkalarının, öğrencilere metni çözümlemeyi öğretip dersi eğlenceli kıldığı; onların derse etkin katılmalarını, iş birlikli çalışmayı öğrenmelerini ve özgüven kazanmalarını sağladı̆̆ı için geleneksel okuma etkinliklerinden daha etkili olduğunu belirtmişlerdir. Öğrenciler olumsuz görüş olarak ise çizer rolündeki kişinin çizim yapamadığını, ilişki kurucu görevindeki kişinin günlük hayatla ilişki kurmada zorlandığını, grup içerisinde tek bir görevde kalmanın sıkıcı olabileceğini, grupların az kişiden oluştuğunu ve soruların sadece bir kişiye sorulduğunu belirtmişlerdir. Bu tür sorunların olması öğretmenin okuma görevlerini bu konuda ilgisiz bir öğrenciye vermesinden kaynaklanabilmektedir. Öğrenciler istedikleri ve yapabilecekleri görevleri üstlendiklerinde bu tür sorunların daha az olacağı söylenebilir. Bunun için öğrenci bir okuma görevini alırken serbest bırakılmalı fakat yapıp yapamayacağı da göz önünde bulundurulmalıdır.

\section{Öneriler}

1. Aynı sınıf düzeyindeki farklı şubeler ile ortak edebiyat halkaları uygulamaları gerçekleştirilerek farklı şubelerdeki öğrenciler arasındaki iletişim ve sosyal ilişkilerin geliştirilmesi sağlanabilir.

2. Edebiyat halkaları temel eğitimden yükseköğretime kadar her düzeyde uygulanabilen eğlenceli ve öğretici bir yöntemdir. Okullarda okuma alışkanlığı ve ilgisinin geliştirilmesi için kullanılabilir.

3. Edebiyat halkaları okuma becerilerini geliştirmenin yanında, öğrencilerin duyuşsal ve sosyal becerilerini de olumlu yönde etkilemektedir. Bu yüzden sınıf içi akran etkileşimi, iletişimde öz güven ve sorumluluk alma becerilerini geliştirmede kullanılabilir.

4. Okuma görevleri ve kitap seçimlerinde öğrencilerin serbest bırakılması gerekir fakat ilk ve ortaokulda öğrencilerin seçtikleri metin ve aldıkları görevlerin üstesinden gelemeyecekleri unutulmamalıdır. Onların düzeyine uygun metinler ve okuma görevleri önerilmelidir.

\section{Kaynakça}

Akın, E., Çeçen, M. A. (2014). Ortaokul öğrencilerinin okuma stratejileri üstbilişsel farkındalık düzeylerinin değerlendirilmesi Muş Bulanık örneği. Turkish Studies, 9 (8), 91-110.

Arl, G. (2014).The effects of sq3r and dr-ta reading strategies used by fifth-grade students on comprehension. Eğitimde Kuram ve Uygulama, 10 (2), 535-555.

Arslan, A. Orhan, S. ve Akçay, A. (2011). Türkçe eğitimi çalışmalarında cinsiyet değişkeni. Gazi Üniversitesi I. Uluslararası Türkçe Eğitimi Sempozyumu Bildiri Kitabı, 88.

Avcı, S. ve Yüksel, A. (2011). Okuma çemberi yöntemine göre kitap okumanın öğrencilere bilişsel ve duyuşsal katkıları. Kuram ve Uygulamada Eğitim Bilimleri, 3 (11), 1285-1300.

Avcı, S., Baysal, N., Gül, M ve Akıncı, Y. (2013). Okuma çemberi yönteminin okuduğunu anlama becerisine etkisi. Kuramsal Ĕ̆itimbilim Dergisi, 6 (4), 535-55.

Aydoğan, R ve Demirtaş, V. Y. (2012). Okumaya karşı olumlu ve olumsuz tutuma sahip 6. sinıf öğrencilerinin Türkçe dersinde kullandıkları okuduğunu anlama stratejileri ve yaratıcılık düzeyleri. Dokuz Eylül Üniversitesi Buca Eğitim Fakültesi Dergisi, (34), 22-41.

Aytan, T. (2018). Perceptions of prospective Turkish teachers regarding literature circles. International Journal of Educational Methodology, 4 (2), 53-6o, doi: 10.12973/ijem.4.2.53.

Balantekin, M., Pilav, S. (2017). Okuma çemberi yönteminin okuduğunu anlama becerisine etkisi. Kirıkale Üniversitesi Sosyal Bilimler Dergisi, 7 (2), 149-170, doi: 10.12973/ijem.4.2.53.

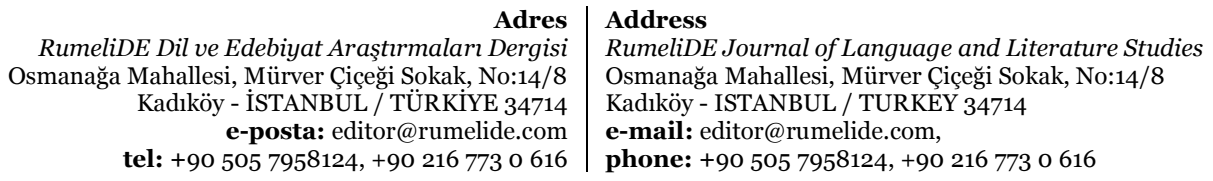


Barone, D., and Barone, R. (2016). Really, “not possible,” “I can’t believe it”: exploring informational text in literature circles. The Reading Teacher, 70 (1), 69-81.

Brabham, E. G., and Willaume, S., K. (2000). Continuing conversations about literature circles. The Reading Teacher, 54 (3). 278-280.

Briggs, S. R. (2010). Using literature circles to increase reading comprehension in third grade elementary students (Unpublished doctoral dissertation). Dominican University of California San Rafael, CA.

Camp, C. S. (2006). The effect of literature circles vs. sustained silent reading (SSR) among eleventh grade English students. Masters Abstracts International, 46 (3), 41-1219.

Daniels, H. (2002). Literature circles: Voice and choice in book clubs and reading groups. Portland, ME: Stenhouse Publishers.

Demirel, Ö ve Epçaçan, C. (2012), Okuduğunu anlama stratejilerinin bilişsel ve duyuşsal öğrenme ürünlerine etkisi. Kalem Eğitim ve İnsan Bilimleri Dergisi, 2 (1), 71-106.

Doğan, B. (2006). Strateji öğretiminin, işbirlikli ve geleneksel sinıflarda okuduğunu anlama becerileri üzerindeki etkileri. Eurasian Journal of Educational Research (EJER), 23, 82-93.

Karasar, N. (2016). Bilimsel araştırma yöntemleri. Ankara: Nobel Akademik.

Karatay, H. (2015). Eleştirel düşünme ve okuma alışkanlı̆̆ becerilerinin geliştirilmesi için edebiyat halkası: Kitap eleştirisi modeli [Literature circle to develop critical thinking and reading habitual abilities: the model of book review]. Milli Egitim, 208, 1-17.

Karatay, H. (2016). 6-8. sınıf öğrencilerinin mecazlı dili anlama düzeyleri. Milli Ĕ̆itim, 45 (210), 265286.

Karatay, H. (2017). The effect of literature circles on text analysis and reading desire. International Journal of Higher Education, 6 (5), 65-75, doi:10.5430/ijhe.v6n5p65.

Karatay, H. (2018). Okuma eğitimi kuram ve uygulama. 3. Baskı. Ankara: Pegem Akademi.

Kavaklı, A. E. (2012). Yüz yılın pedagojik yanlışı karma eğitim sorgulanıyor. Eğitime Bakış Eğitim Öğretim ve Bilim Araştırma Dergisi, 22:39.

Keklik, S. (2009). On bir yaşına kadar çocukta dil edinimi (Yayınlanmamış Doktora Tezi). Marmara Üniversitesi Eğitim Bilimleri Enstitüsü, İstanbul.

Köğce, D., Özpınar, İ., Mandacı Şahin, S. ve Yenmez Aydoğan, A. (2014). Öğretim elemanlarının 21. yüzyll öğrenen standartları ve yaşam boyu öğrenmeye ilişkin görüşleri. Dicle Üniversitesi Ziya Gökalp Ĕ̆itim Fakültesi Dergisi, 22, 185-213.

Marchiando, K. (2013). Creating lifelong readers: Student ownership and peer interaction in literature circles. Illinois Reading Council Journal, 41(3), 13-21.

McElvain, C. M. (2010). Transactional literature circles and the reading comprehension of English learners in the mainstream classroom. Journal of Research in Reading, 33 (2), 178-205.

Meredith, J. (2015). The effects of literature circles on second graders' reading comprehension and motivation (Unpublished master thesis). Graduate Programs in Education Goucher College.

Mizerka, P. M. (1999). The impact of teacher directed literature circles versus student-directed literature circles on reading comprehension at the sixth-grade level (Unpublished doctoral dissertation). University of Illinois, IL.

Olsen, A.S.W. (2007). Literature circles and ninth grade students: A student-centered approach to reading (Unpublished master's thesis). Southwest Minnesota State University, Marshall, MN.

Purifico, J. (2015). Literature circles: In class and online discussions (Master Thesis). Rowan University, Department of Language, Literacy, and Special Education College of Education, Erişim: http://rdw.rowan.edu/etd/486.

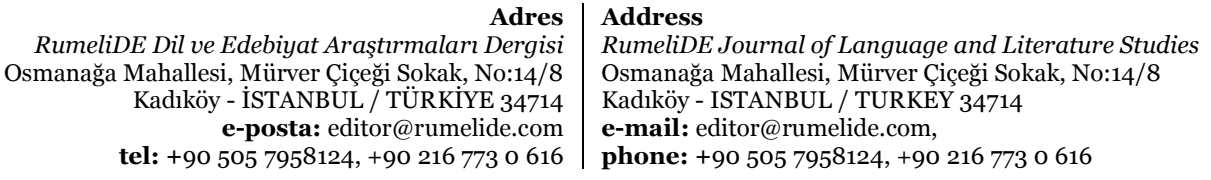

RumeliDE Dil ve Edebiyat Araştırmaları Dergisi e-posta: editor@rumelide.com tel: +90 505 7958124, +90 2167730616 
Sallabaş, M. E. (2008). İlköğretim 8 sinıf öğrencilerinin okumaya yönelik tutumları ve okuduğunu anlama becerileri arasındaki ilişki. İnönü Üniversitesi Ĕ̆itim Fakültesi Dergisi, 9 (16), 141-155.

Snow, C. E. (2002). Reading for understanding: Toward a research and development program in reading comprehension. Santa Monica, CA: Rand Corporation.

Soysal, 亡̇. (2019). Edebiyat halkasınm 5. sımf. öğrencilerinin okuma becerilerine etkisi (Yayımlanmamış yüksek lisans tezi). Bolu Abant İzzet Baysal Üniversitesi, Bolu.

Stabile C. (2009). Are literature circles an effective reading strategy for struggling readers? (Unpublished master's thesis). Ohio University.

Tercanlıŏ̆lu, L. ve Akarsu, O. (2012). Okuma eğitiminde okuma teorileri. Atatürk Üniversitesi Sosyal Bilimler Enstitüsü Dergisi, 16 (3), 59-72.

Tracey, D., and Morrow, L. M. (2006). Lenses on reading: An introduction to theories and models. New York, NY: Guilford Press. 